\title{
The Impact of School Culture in Mediating Teachers Innovation and Emotional Intelligence on School Effectiveness
}

\author{
Sri Rahayu*, Arif Rahman Hakim \\ Department of Primary School Education \\ University of Kanjuruhan Malang \\ Malang, Indonesia \\ *srisk@unikama.ac.id, arifrahman@unikama.ac.id
}

\author{
Iskandar Ladamay \\ Department of Pancasila and Civic Education \\ University of Kanjuruhan Malang \\ Malang, Indonesia \\ ladamay@unikama.ac.id
}

\begin{abstract}
The school effectiveness is influenced by interaction between external and internal factors. This research aims to examine the mediating effect of school culture between teacher concern innovation and emotional intelligence on school effectiveness. Questionnaires were distributed to 333 teachers of elementary school and analyzed using Structural Equation Models (SEM) with AMOS 18.0 Software. The results show that teacher concern innovation was significantly and positively related to school culture but correlate indirectly on school effectiveness. The positive relations between emotional intelligence and school culture and school effectiveness were also significant. It was found that school culture is able to mediate teacher concern innovation on school effectiveness. The other finding is that emotional intelligence and school culture have direct effect on school effectiveness. These findings suggest that the higher teacher concern on innovation and emotional intelligence promote the positive school culture and effectively improved the school education quality.
\end{abstract}

Keywords: emotional intelligence, mediating effect, school effectiveness, school culture, teacher innovation

\section{INTRODUCTION}

In general, the aim of primary school management is to realize primary schools as educational institutions that can achieve effectiveness. Initially, school effectiveness is often seen in terms of completeness of facilities and infrastructure, namely the view of production theory (prodiction function theory), but today school effectiveness is determined more by the management of education, including the expectations of teachers and students to achieve high learning outcomes, through the process learning. The learning process is a key educational problem so far. The learning process in the classroom is the black box (black box) that we have to find the place and the key.

Rahayu, et.al stated that the effectiveness of education in schools is influenced by interactions between external and internal factors [1]. Clarke \& Gibson states that environmental factors, technology, strategies, structures, processes, and cultural climate influences that cause organizational effectiveness, so leaders must pioneer, create, and encourage the growth of cultural quality in schools by thinking ahead and being able to handle changes in creating renewal. Education towards quality. Thus, the predicate of an effective school can be achieved.

The results of Serdyukov's research [2] state that education really needs innovations that can help produce high-quality learning outcomes that are needed throughout the system. Elementary schools need innovation at a "high level" especially in guiding students according to their abilities and letting teachers do something to progress their career [3]. Rahayu, et.al in his research stated that teacher innovation contributes to school effectiveness. This is in line with the opinion of Lipham et.al. That school effectiveness can be assessed through the activities of adopting innovation programs.

Examining the factors that influence school effectiveness, it appears that emotional intelligence is one of the important attributes for someone to carry out their work effectively. Moore [4] in his research stated that emotional intelligence can be the difference between high-performing and lowperforming schools and leaders who have high EQ are more skilled in leading change and a commitment culture among their staff.

Besides that, theoretically and empirically culture influences effectiveness. Deal, et.al (in Hoy \& Miskel) state that successful companies that are extraordinary need a strong organizational culture in spurring effectiveness [5]. Cavanagh \& Dellar (in Ali) said that there is a relationship between school culture and school effectiveness, which means school culture has a major role in school improvement that leads to school effectiveness [6]. Denison (in Sutrisno) states that organizational culture influences effectiveness, especially because in organizational culture there is involvement, consistency, adaptation and clarity of mission [7]. Furthermore Ali, et.al said that it was important to understand school culture as an internal factor to study school effectiveness.

Meanwhile, looking into the field about the real condition of the effectiveness of primary schools in Indonesia has not 


\section{METHODS}

been able to provide satisfactory results, as measured by the low ability of students to reason, elementary school hours in Indonesia are more in comparison to other countries. Comparison in one year in Indonesia applies 1,095 study hours, whereas in South Korea only applies 903 study hours per year and in Japan only applies 712 study hours per year. However, their educational results are ranked in the world [8].

Based on the Human Development Index (HDI) of Indonesia was ranked 113th in 2015. The HDI rating for Indonesia in 2014 was 110 . In the same year, education spending fell to $0.3 \%$ from $3.6 \%$ to $3.3 \%$ from APBD. The literacy ability of adults aged $15+$ rose to $1.1 \%$ from $92.8 \%$ to $93.9 \%$. The number of students dropping out of school declined from $11 \%$ to $18.1 \%$. The education gap remains at $20.8 \%$.

In Malang City itself, especially in Lowokwaru District, Rumidjan et al. said that elementary school teachers in general had difficulty in improving the quality and effectiveness of learning in their elementary schools. That is because teachers have not been able to innovate in the learning process whether it is related to methods or models of learning, material, and learning media. Therefore, to achieve school effectiveness, it is expected that teachers have a concern to innovate in learning, have high emotional intelligence, as well as teachers are able to create a positive atmosphere and behavior both in the classroom and in the school environment. So that an effective school predicate can be achieved [9].

Elementary school teachers in Lowokwaru Subdistrict, Malang City according to Rumidjan, et.al do not have sufficient insight and skills to innovate to make fun learning media that can enable students to be active, creative, and fun in their learning activities. Supported by Setiono's opinion that teachers still find it difficult to innovate to develop their own teaching materials so that the teaching materials used by teachers are less varied, unattractive, ineffective and low absorbency because they do not fit the needs, characteristics, and learning environment of students [10].

Meanwhile in Malang, violence and violence by teachers and principals were still common, as was the case in the 5th grade students of Purwantoro 7 Elementary School Malang, who experienced violence from their teachers with wounds as wide as $3 \mathrm{~cm}$ on their cheeks due to being slapped and pinched [11]. This also happened to 4 students of Malang Lowokwaru Elementary School who were shocked by their school principal [12]. This shows that the level of emotional intelligence of our educators is still low. In addition, it is also known that primary school culture especially in Malang Regency is still low [13].

Finally, based on theoretical studies and real conditions in the field as described above, it appears that there will be many factors that affcets the effectiveness of schools. Therefore, the research on the effect of school culture in mediating teacher concern innovation and emotional intelligence on school effectiveness needs to be explored.
This work used a quantitative approach with explanatory research. Questionnaires surveys was carried out to explore the relations among school culture, teacher concern innovation, and emotional intelligence on school effectiveness. The questionnaires consist several questions that represent research variables (Table 1).

TABLE I. RESEARCH VARIABLES

\begin{tabular}{|l|ll|}
\hline \multicolumn{1}{|c|}{ Variables } & \multicolumn{1}{c|}{ Indicators } \\
\hline Concern on innovation & - & Self \\
& - & Task \\
& - & Impact \\
\hline Emotional intelligence & - & Empathy \\
& - & Ability to have self-expression \\
& - & Self-Control \\
& - & Self-Awareness \\
& - & Social Skill \\
\hline School culture & - & Professional Orientation \\
& - & Organizational Structur \\
& - & Quality of Learning Environment \\
& - & Focusing on the Student \\
\hline School effectiveness & - & The Clear of Vision and Mission \\
& - & The Positive Atmosphere of the School \\
& - & High Expectation \\
& - & Monitoring \\
& - & Learning Opportunity \\
& - & Parents Involvement \\
\hline
\end{tabular}

The respondents were the Civil Servant teachers of State Elementary Schools in Malang City. The number of populations was 1987 teachers. By using Isaac and Michael table with the $5 \%$ error rate of sampling, 333 of the teachers were obtained to be the samples. The sampling was done using probability sampling method with Proportional Area Random Sampling technique that is proportional sampling for each area. The data analysis was conducted using Structural Equation Models (SEM).

The model was validated by measuring the goodness of fit model prior to use in analyzing the influence of school culture as mediator of teacher concern innovation and emotional intelligence on school effectiveness. The results show that all criteria show the good model and thus the model can be categorized suitable and feasible to be used. Therefore, the interpretation for further discussion can be carried out.

\section{RESULTS AND DISCUSSION}

\section{A. Results}

Structural Equation Model (SEM) analysis by using AMOS 18.0 was employed to test the hypothesis proposed by the researchers. As the basis to test the hypothesis, Critical ratio $(\mathrm{Cr})$ from the result of output Regression Weight was also used. That hypothesis would be accepted if $p$ value $<5 \%$ significance. The analysis results are listed in Table 2. 
TABLE II. STANDARDIZED STRUCTURAL ESTIMATES OF THE STRUCTURAL MODEL DiRECT EFFECT

\begin{tabular}{|l|l|l|l|c|}
\hline \multicolumn{2}{|c|}{ Variables } & Estimate & C.R & P \\
\hline School Culture & Caring for Innovation & 0.333 & 4.904 & 0.000 \\
\hline School Culture & Emotional Intelligence & 0.223 & 3.364 & 0.000 \\
\hline School Effectiveness & Caring for Innovation & 0.443 & 6.988 & 0.000 \\
\hline School Effectiveness & Emotional Intelligence & 0.270 & 4.829 & 0.000 \\
\hline School Effectiveness & School Culture & 0.285 & 4.879 & 0.000 \\
\hline
\end{tabular}

Table 3 shows that there is a significant and positive relations among teacher's care of innovation and emotional intelligence on the school culture at 5\% level. It means that the teacher's care of innovation and teacher's emotional intelligence contribute to enhancing the school culture. This result shows that the more the teachers care of innovation, the school culture will upgrade $33.3 \%$, while the higher the teacher's emotional intelligence, the school culture increases $22.3 \%$.

The result of the effect of the teacher's care of innovation and emotional intelligence, as well as school culture on the school effectiveness is significant at $5 \%$ level. It means that the teacher's care of innovation and emotional intelligence, as well as school culture contribute to improve the school effectiveness. This result indicates that the more the teacher innovates, the school effectiveness increases $27 \%$, while the better the school culture, the school effectiveness enhances $28.5 \%$.

The test of indirect effect was employed from some results of the test of the direct effect. The complete results of the test of direct and indirect effects are presented in Table 3.

TABLE III. THE RESULT OF TEST OF INDIRECT EFFECT HyPOTHESIS

\begin{tabular}{|l|l|l|l|}
\hline \multicolumn{1}{|c|}{$\begin{array}{c}\text { Effect Between } \\
\text { Variables }\end{array}$} & $\begin{array}{c}\text { Direct } \\
\text { Effect }\end{array}$ & $\begin{array}{c}\text { Indirect Effect } \\
\text { through School } \\
\text { Culture }\end{array}$ & $\begin{array}{c}\text { Total } \\
\text { Effect }\end{array}$ \\
\hline $\begin{array}{l}\text { Caring for Innovation on } \\
\text { School Culture }\end{array}$ & 0.333 & - & 0.333 \\
\hline $\begin{array}{l}\text { Emotional Intelligence } \\
\text { on School Culture }\end{array}$ & 0.223 & - & 0.223 \\
\hline $\begin{array}{l}\text { Caring for Innovation on } \\
\text { School Effectiveness }\end{array}$ & 0.443 & $\begin{array}{l}0.333 \quad \text { x 0.285 } \\
0.095\end{array}$ & 0.538 \\
\hline $\begin{array}{l}\text { Emotional Intelligence } \\
\text { on School Effectiveness }\end{array}$ & 0.270 & $\begin{array}{l}0.223 \quad \text { x 0.285 } \\
0.066\end{array}$ & 0.336 \\
\hline $\begin{array}{l}\text { School Culture on } \\
\text { School Effectiveness }\end{array}$ & 0.285 & & 0.285 \\
\hline
\end{tabular}

As can be seen in Table 3, the school culture was observed could mediate teacher's caring of innovation and teacher's emotional intelligence to the school effectiveness. This result shows that the teacher's caring of innovation and teacher's emotional intelligence could increase the school culture that gives effect to the school effectiveness.

\section{B. Discussion}

1) Direct correlation between teacher's care of innovation and school culture: Based on the result of the inferential statistical analysis, there is a significant direct correlation of teacher's care of innovation to the school culture. This outcome indicates that the higher the teacher's care of innovation, the school culture is higher as well.

The positive school culture is due to the teacher's care of innovation. The teacher's care of educational innovation is shown by three indicators namely self, task, and impact. The indicator that is considered greatly and strongly contributing to form the teacher's care of innovation is task. This condition shows that the teacher's care of innovation in learning is formed since they know more the information of time, commitment, and resources needed in the innovation.

The result of this study strengthens the previous study conducted by Atmono stating that there is a significant relationship between teacher's care of innovation and the school culture of State Elementary Schools in Banjarmasin City. This case means that the higher the teacher's care of innovation, the school culture will increase as well [14].

In line with the diagram of four pillars of innovation in The Conference Board of Canada (in Pollock) that describes the correlation between innovation and the school culture is reciprocal that is innovation influences the school culture and the school culture influences innovation [15]. This case can be seen in the Elementary School of Villa Nova (in Pollock); there is an initiative to be commemorated, the tolerated risk, the respected learning, and the change. However, it is different from the research result of Sanz-valle, et.al. addressing that the school organizational culture can enhance the school organizational innovation [16].

2) The direct relationship between emotional intelligence and school culture: Based on the results of inferential statistical analysis there is a significant direct relationship between the emotional intelligence and school culture. This result shows that the higher the teacher's emotional intelligence, the better the school culture. To build the conducive atmosphere of school culture, the teacher's role is urgently required through the teacher's emotional intelligence. Emotional intelligence is a sequence of ability, competency, and non-cognitive skill influencing someone's ability to successfully fulfill the environmental demand and suppress [17]. The emotional intelligence is an individual's attitude to understand the others from his/her point of view; it is clear that the emotional intelligence can influence the culture of someone who has the high empathy; he/she will always try to understand the other's thought and emotion and give the value.

Emotional intelligence that can influence the school culture is applied to five indicators namely empathy, the ability of self-expression, self-control, self-awareness, and social skill. Subsequently, from the aspect of loading factor value of each indicator considered greatly and strongly contributing to form the variable of emotional intelligence is self-control. This condition indicates that self-control is one of the forms of emotional intelligence regarded the most effective where the teacher has the good emotional intelligence if he/she can well adapt to the environment so that the class situation is friendly and he/she has the ability to 
include in cooperative work and teamwork when doing the daily duties and the ability to develop the learning program.

The result of this study supports the previous study conducted by Pervez, et.al. showing the significant influence of emotional intelligence (EQ) on the school culture. Moreover, if the emotional intelligence increases, the effect on the school culture also enhances [18]

3) Direct correlation between teacher's care of innovation and school effectiveness: Based on the results of the inferential statistical analysis, there is a significant direct correlation between teacher's care of innovation and school effectiveness. This result shows that the higher the teacher's care of innovation, the higher the school effectiveness.

The teacher's role in innovation is definitely needed since the teacher can be said as the one playing the role in the learning process in the class that should be able to upgrade his/her ability to make an effective and efficient learning media that finally it can improve the school effectiveness. The enhancement of the school effectiveness through the teacher's role in innovation can be undertaken by three indicators namely self, task, and impact. The indicator that is considered greatly and strongly contributing to the innovation is task. This condition indicates that the teacher's care of innovation is formed since he/she knows the demand of innovation in the learning and knows more the information of time, commitment, and the effort required in innovation.

The result of this study strengthens the previous literary study conducted by Huang in the primary and secondary schools. That work concluded that the schools that intend to be successful in applying innovation must carefully design that ultimately it can increase the school effectiveness [19]. From the research results of Chang, et.al, one of the final results of structural equation model is a relationship between organizational innovation and school effectiveness indicated by the score of $\beta 21=0.84, p<0.05$ meaning that the development of organizational innovation is a model of effective publication to reach the school effectiveness [20]. Serdyukov stated that education urgently needs effective innovation that can help to result in high-quality learning needed in all systems. Improving the quality and innovation of the education will positively impact on the education and all people. Atmono mentioned that there is a significant correlation between the teacher's care of innovation and the school effectiveness in the State Elementary Schools in Banjarmasin City. On the basis of the results of the inferential statistical analysis which has bee done by Rahayu, et.al state that a significant direct relationship is found between teacher innovation and school effectiveness. Therefore, the higher the teachers concern for innovation, the higher the school effectiveness. Teacher innovation is necessary because teachers themselves are instrumental in the learning process. This case means that the higher the teacher's care of innovation, the higher the school effectiveness.

4) The direct correlation between emotional intelligence and school effectiveness: Based on the result of the inferential statistical analysis, there is a significant direct correlation between emotional intelligence and school effectiveness. This result means that emotional intelligence is the ability to understand the emotion and use the primary source of information to understand self and the others, as the way to reach a purpose. To achieve the goal of the school, the teacher as the educator has a very significant role. As an educator, the teacher is influenced by the external factors causing him/her less maximum in his/her works. One of the factors that influence the teacher's performance is emotional intelligence. Emotional intelligence also means the mental ability that assists us to control and understand our and the others' feeling that guide to the ability to control such feelings. So, the smart people, emotionally, do not only have the emotion or feelings but also understand what the meaning of those feelings.

The school will effectively run and it relates to the teacher's emotional intelligence. The teacher's emotional intelligence is formed due to four indicators namely the ability of self-expression, self-control, self-awareness, and social skill. Subsequently, from the aspect of loading factor of each indicator, the indicator that is regarded greatly and strongly contributing to form the variable of emotional intelligence is self-control.

The result of this work supports the previous study conducted by Jiwa stating that there is a significant and positive relationship between the teacher's emotional intelligence and the school effectiveness [21]. It is also in line with the research result of Nureni finding that there is a strong correlation between the emotional intelligence and administrative effectiveness of provost. Nureni suggested to the federal training center in Nigeria to regularly renew them by enhancing the emotional intelligence since it will impact on the administrative effectiveness that finally it will upgrade the school effectiveness [22].

The research results of Moore concluded that emotional intelligence and intelligence guided emotion must be motivated for the school administrator. University, school council and educational department of a country must take into account the building of emotional intelligence and mentoring program for the school administrators. The school administrators who have high emotional intelligence will not only have a tight relationship with their colleagues, teacher, parents, and students but also be more effective in leading the change and starting the school reformation.

Van Rooy and Viswesvaran concluded that emotional intelligence can be consedered a valuable prodictor of work performace [23]. Effective middle schools and principals must understand and manage emotions to implement and lead school reform. Fahanani concluded that a significant positive realationship exists between teachers' emotional intelligence and school effectiveness. Rahayu, et.al in her research state that a significant direct relationship is found between emotional intelligence and school effectiveness.

5) The direct correlation between school culture and school effectiveness: Based on the results of the inferential 
6) Indirect correlation between teacher's care of

statistical analysis, there is a significant direct correlation between the school culture and the school effectiveness. This result shows that the higher the school culture, the higher the school effectiveness.

The success of the certain educational institution is supported by not only the complete facility and infrastructure, the high-quality teachers, or good input of students but also the school culture playing important role in improving the school effectiveness. This case is because the school culture is a soul of a school that gives meaning to the educational activity of that school; if the school culture is weak, it will be not conducive to form the effective school. On the contrary, the strong school culture will facilitate the increase in school effectiveness.

This condition indicates that a school will be effective if it can create a good culture shown by the regulation, rule, and procedure applied in the school that become the flexible guide for the teacher to solve the problems in the school. The school is always influenced by its environment and thus the headmaster views that school is an open system. The headmaster and teachers develop the school vision for the school advance in the future. The headmaster always practices two-way communication so that the teachers and staffs are not reluctant to each other share their problems, give opportunity to the students who can fast learn to get the enrichment and give remedy for the left-behind students in every learning, are willing to additionally help the students to gain the good achievement and the students' parents have been involved in any kinds of activities held by the school.

The result of this research strengthens the previous outcome found by Ali that there is a correlation between school culture and school effectiveness from SEM analysis and rho spearman calculation, the score of $p<0.01$. It is in line with the research undertaken by Atmono mentioning that there is a significant relationship between the teacher's carie of innovation and school culture in the State Elementary Schools in Banjarmasin City. This case means that the higher the teacher's care of innovation, the school culture will increase. Empirically, the school culture influences the school effectiveness such as the research result of Ali et.al stating that there is a significant correlation between the school culture and the school effectiveness.

Besides, Sammons \& Bakkum addressed that to create an effective school and improve the effectiveness, the school must focus on creating the positive school culture [24]. The research results of Glusac, et.al. indicates that the school culture strongly and positively impacts on the teaching and learning in the primary school in Serbia [25]. Ouchi (in Hoy \& Miskel) asserted that the success of the effective organization in both Japan and America is the function of the special corporate culture that is the integrally consistent culture indicated by the value of friendliness, trust, cooperation, teamwork, and communal egalitarianism. Cheng in Xiaofu and Qiwen revealed that school effectiveness shows the ability of schools to perform social function of humanity, political, culture, and educational functions. innovation and the school effectiveness through school culture: Based on the results of the inferential statistical analysis, it is found that the school culture mediates the relationship of teacher's care of innovation and school effectiveness.

This result means that the teacher's care of innovation such as knowing the demand of innovation in learning and knowing more information of time, commitment, effort, and resources needed in the innovation, can improve the school culture such as organizational culture and focusing on the students that finally impacting on the increase in the school effectiveness reflected by the school that always positively communicates with the students' parents and community.

7) Indirect relationship between emotional intelligence and school effectiveness through school culture: Based on the results of the inferential statistical analysis, it is found that the school culture mediates the relationship between the emotional intelligence and the school effectiveness.

This result explains that the teachers who have the high emotional intelligence indicated by their ability to adapt to the environment so that the atmosphere in the class is intimate, have the ability to include in teamwork when doing their daily duties and the ability to develop the learning program that can enhance the school culture such as organizational structure and focus on the students that finally it impacts on the increase in the school effectiveness reflected by the school that always positively communicates with the students' parents and cooperates with them and community.

\section{CONCLUSION}

The teacher's care of innovation and emotional intelligence, as well as the school culture, influences the school effectiveness. The study results show that the school culture mediates the effect of the teacher's care of innovation and emotional intelligence on the school effectiveness. The headmaster should take into account the school culture through supervision started with a class visit by the headmaster and teacher, assessment of work mechanism and output, group research on the condition of the school and teacher, checking the presence list or teacher presence, and filling the daily journal in the class. These cases could improve the teacher's professional competency and the school culture that can mediate the effect of the teacher's care of innovation and emotional intelligence on the school effectiveness.

\section{REFERENCES}

[1] S. Rahayu, N. Ulfatin, B.B. Wiyono, A. Imron, M.B.N. Wajdi. "The Professional Competency Teachers Mediate The Teacher Innovation and Emotional Intelligence on School Security". Journal of Social Studies Education Research. 9 (2): 210-227. 2018.

[2] P. Serdyukov, "Innovation in education: What Works, What Doesn't, and What To Do About It?". Journal of Research in Innovative Teaching \& Learning. 10 (1). 4-33. 2017. 
[15] P. Pollock, "The Four Pillars of Innovation: An Elementary School Perspective". The Innovation Journal: The Public Sector Innovation Journal. 13 (2): 2-20. 2008.

[16] R. Sanz-Valle, J.C. Naranjo-Valencia, D. Jimenez-Jimenez, and L. Perez-Caballero, "Linking Organizational Learning With Technical Innovation and Organizational Culture". Journal of Knowledge Management. 15 (6). 997-1015. 2011.

[17] S.J. Stein and H.E. Book. Ledakan EQ: 15 Prinsip Dasar Kecerdasan Emosional Meraih Sukses. Bandung: Kaifa Offset. 2002.

[18] Z. Pervez, M.A. Dahar, and R. Tahira, "Impact of Emotional Intelligence of Principals on School Culture at Secondary Level". Sci.Int (Lahore). 28 (1): 593-596. 2016.

[19] H.M. Huang, "The Research of School Innovation and Effectiveness". International Conference on Educational and Management Innovation. 30: 27-31. 2012.

[20] I. Chang, H. Yen, and C. Hsu. The Relationship Among Organizational Learning, Organizational Innovation and School Effectiveness: A Test of the Mediated-Effects Model. China: American Educational Research Association. China University of Technology Repository, (Online), (http://192.192.83.167/handle/987654321/440), diakses 7 Mei 2018. 2011.

[21] I.M. Jiwa, Hubungan antara Kepemimpinan Kepala Sekolah, Kecerdasan Emosional Guru, dan Kompetensi Guru dengan Keefektifan Sekolah pada Sekolah Menengah Pertama Negeri di Kabupaten Tabanan Provinsi Bali. Malang: Karya Ilmiah UM Library. 2010.

[22] A.A. Nureni. Emotional Intelligence and Administrative Effectiveness of Provost of Federal Training Centres in Nigeria. Journal of Research \& Method in Educational. 4(5):15-24. 2014.

[23] V.D.L Rooy and C. Viswesvaran, "Emotional Intelligence: A MetaAnalytic Investigation of Predictive Validity and Nomological net". Journal of Vocational Behaviour. 65 (1). 71-95. 2004.

[24] P. Sammons and L. Bakkum, "Effective School, Equity and Teacher Effectiveness: A Riview to the Literature". Profesorado. 15 (3): 9-26. 2011.

[25] D. Glusac, I. Tasic, M. Nikolic, E. Terek, and B. Gligorovic, "A Study of Impact of School Culture on the Teaching and Learning Process ini Serbia Based on School Evaluation". Research Gate. 373.31 (497.11):255-268. 2015 